\title{
1 \\ The World of a Woman
}

The Wahgi River meanders through a fertile green basin in the Central Highlands of New Guinea. The Minj people (called after the government station and the sub-district in the Western Highlands which it serves) inhabit the part of the valley that lies south of the river. They build their dwellings on wooded spurs that reach out towards the centre of the valley basin and in narrow side-valleys formed by tributaries that rise in the Kubor Mountains and flow into the Wahgi. The valley is bounded by mountains, the Kubors in the south and the Wahgi-Sepik Divide in the north. Minj men venture beyond these mountains to trade and, in modern times, to accompany the occasional patrol by Distårict Administration, Malaria Control, or missionary officials; but the life of their womenfolk takes place within the confines of the Wahgi Valley itself and the Middle Wahgi region in particular.

Each married woman has her own house, still typically a long low building designed to accommodate the pigs that are in her care. She herself sleeps in a tiny back room, where the only access to her quarters is between rows of pig stalls. Traditionally the pigs and the taboos associated with them served to chaperone the woman in the absence of her husband. Pigs were thought to be sensitive to the smell of human semen and to sicken and die in response to it. The Minj people so valued pigs that, improbably as it may seem to peoples with a different idea of these animals, a man's respect for his clan's aspirations to protect and increase its supply of pigs acted as a brake on any tendency he might have to be intimate with his wife in her house rather than his own or to seek to enter the houses of other men's wives in order to obtain illicit satisfactions. A central hearth 
dominates the living room of the woman's house, though she cooks most meals for her domestic group in the cooking grove outside the house in fine weather.

A distinct devaluation of pigs in recent years led to a few essays in constructing separate buildings (mostly now abandoned) for animals, an increase in adultery, and an increase also in the extent to which men are prepared to sleep with their wives inside 'women's houses' which accommodate pigs. A speech delivered by an English-speaking mission schoolboy at the opening of the successful House of Assembly candidate's European-style house in March 1964 made slighting references to the unenlightened tradition that led 'everyone' to sleep 'in the same houses as pigs'. It was clear that he had no conception of the way women and pigs protected each other in former times.

The concern of these people for pigs dominated their life. Pigs and women were men's pretexts for fighting in the old days. This obsession has given way, among those who live near the Government Station, to anxiety about money; but any attempt to understand how they are adapting to the demands of modern living must take account of their traditional relationship with pigs, which continues among people who live far from the Station. They ate pork mostly on ritual occasions: at marriage and death payments and also at the climax of the Pig Ceremonial their own clans and those of their maternal and affinal relatives ${ }^{1}$ held; pigs that sickened and died were the only ones eaten informally at home. In their traditional theology, Bolim The Great Spirit who was propitiated in order to ensure fertility in the clan's women was matched by Geru the Great Spirit who was propitiated in order to ensure fertility and well-being in the clan's pigs. Geru's house, built anew for each Pig Ceremonial, was the site of those parts of the boys' initiation that could not be conducted in the bush. Dead parents had to be propitiated with the sacrifice of pigs, and when the sacrifice failed to alleviate the sickness or misfortune blamed on the ghosts a medium might reveal during a séance that the ghosts had been angered further by the sacrifice of the wrong pig. Each pig had a personal name and when the time came for its owner to slaughter it the woman who had cared for it grieved as for a beloved person. 


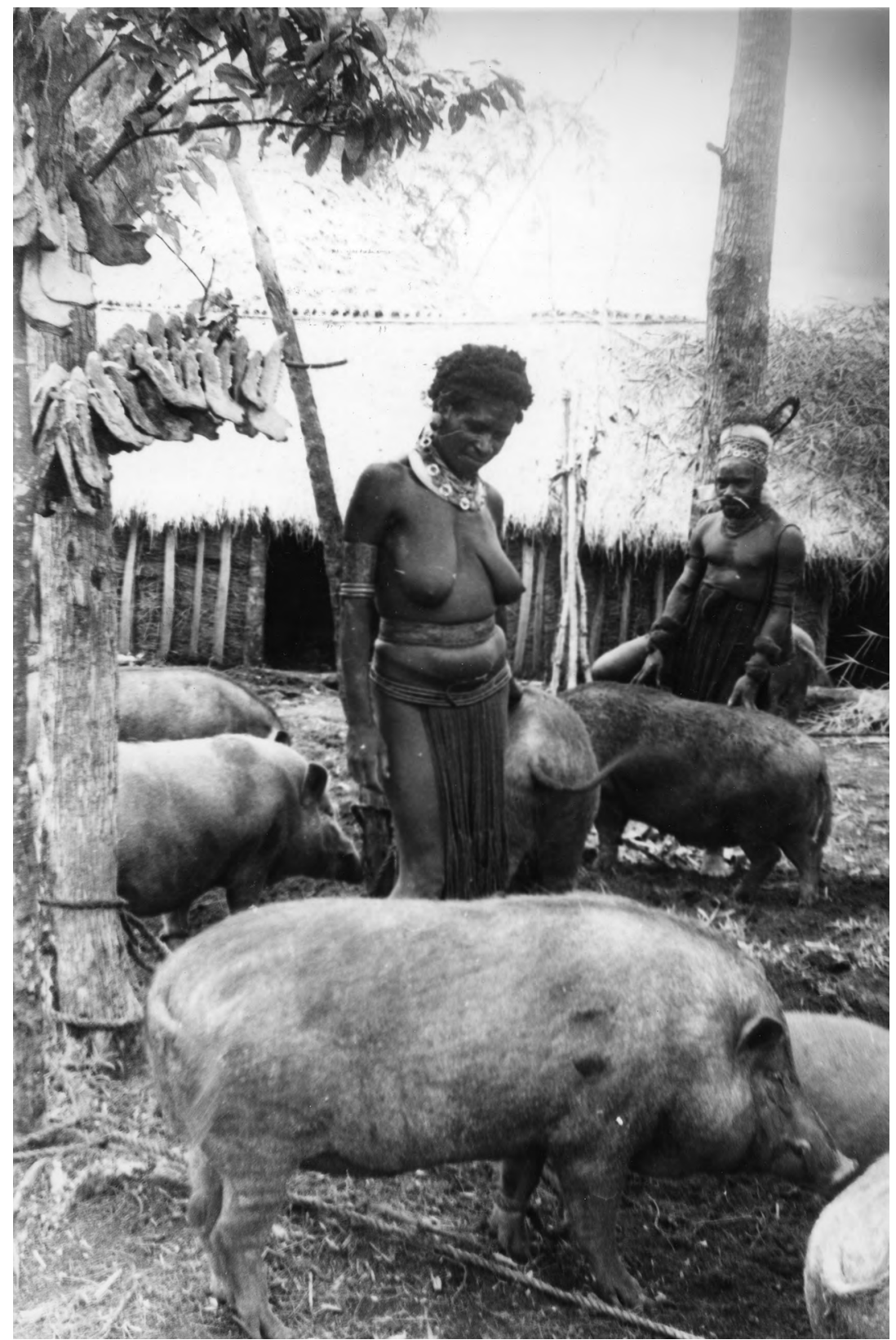

Photograph 9: Woman and pigs

Source: Album 2 Reay 440/1194, Noel Butlin Archives 
WIVES AND WANDERERS

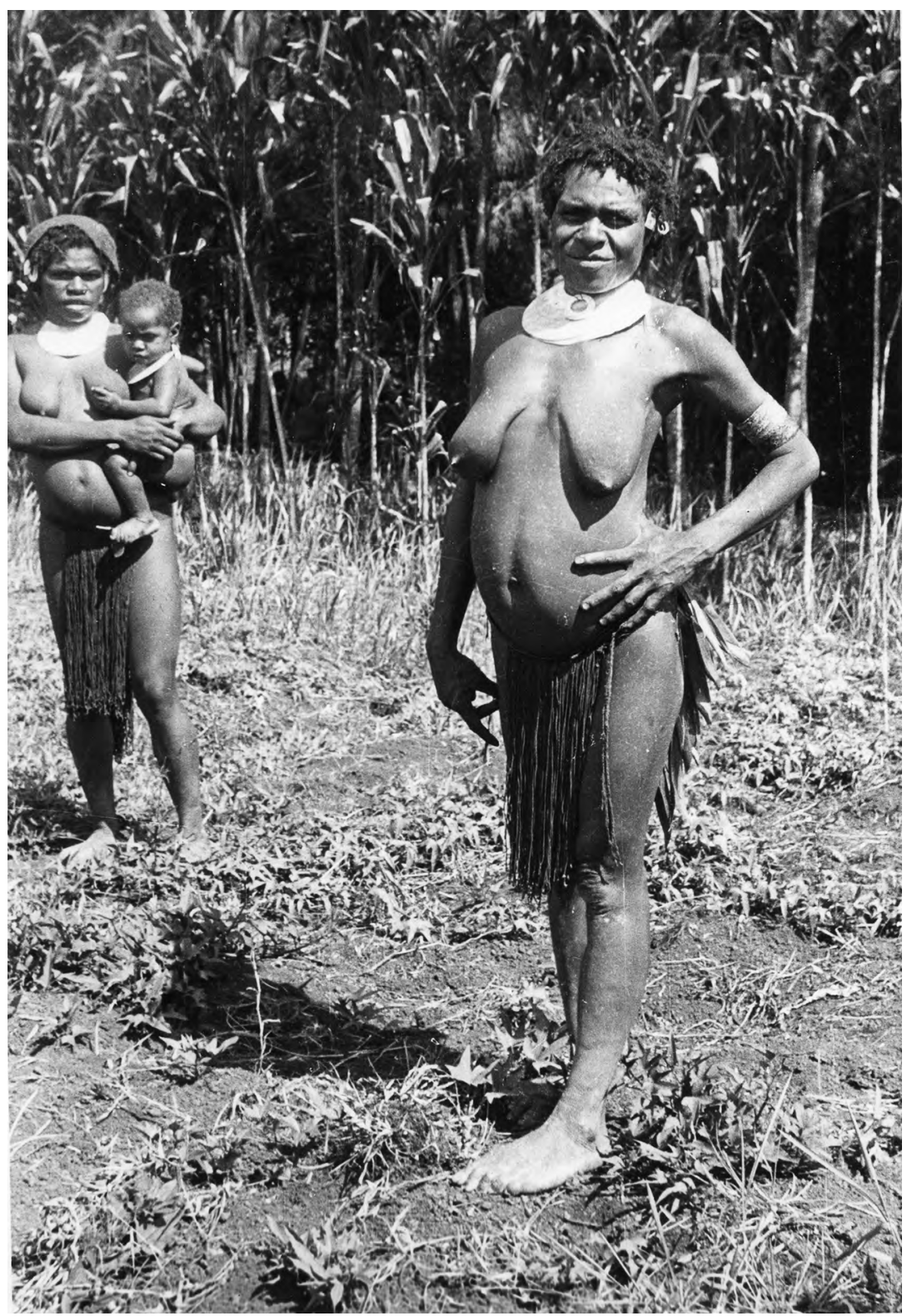

Photograph 10: Two women and child

Source: Album 2 Reay 440/1194, Noel Butlin Archives 
Pigs as well as people depended traditionally on the sweet potato for the bulk of their food. The culture of the Middle Wahgi at the time of European penetration of the Highlands in the early 1930s was shaped largely from the way a lively and sensible people, who nevertheless had a strong magical bent, adapted their needs to these two major resources, pigs and sweet potatoes. And yet it seems likely that pigs, which we know were not indigenous to Papua New Guinea, did not arrive in this part of the Highlands till the eighteenth century. And we now know that the sweet potato has been in Papua New Guinea no more than 350 years. This means that the 'traditional' culture of the Middle Wahgi must be recent.

Indeed there is much to suggest to an ethnographer that this culture is so recent that if we could document the past as thoroughly as we can document the present we would find that it was simply a phase in cultural adaptation and development. The task of reconstructing that past is too great a challenge to be ignored, though much of our reconstruction must at present be speculative. An intriguing feature of recent Middle Wahgi culture is the people's failure to make practical use of the volcanic stone mortars and pestles which abound in the area but which they treated as antiquities of uncertain origin. It was as if these objects had been made and used by a different people who had inhabited the valley in earlier times and had abandoned them there when a more energetic people arrived and dispersed them. It seemed unlikely that a superior technology could be supplanted so easily; why did the present-day people, who are quick to adopt new skills when these are useful to them, not take to using the pestles and mortars? The answer, that these objects could not have appeared to be of use to them, still left much unexplained. The Bulmers' archaeological research (1964a, $1964 b)^{2}$ suggests that the modern people's guess that the artefacts must have been made by their own ancestors (the 'ancestral spirits') is almost certainly right.

The Minj people's own view of the past gives a look of newness to their culture. They see their oral history in two periods. The recent past is simply a series of events in the changing relationships between clans that have existed during the lifetimes of their fathers and grandfathers. The verbal record of these events is a kind of social history or, more precisely, a political history dealing with the two topics of warfare and group segmentation. There seems

2 See Bulmer, R.E. 1964a. 'Prehistoric stone implements from theNew Guinea Highlands', Oceania 34: 246-268; Bulmer, R.E. 1964b. 'Radiocarbon dates from the New Guinea Highlands', Journal of the Polynesian Society 73: 327-328. 
to be no reason why we should doubt the authenticity of the main facts that make up this record. But the facts, as I think we can say they are unless we do encounter evidence for doubt, are undated. Some important events of this recent history, which occurred before Minj people living in 1953-55 were born, could have taken place during the lifetime of their grandfathers or of much earlier ancestors. The time when one's grandfather was a young man seems a long time ago when there is no firm record of that time or any earlier period. We shall probably never know how much is missing from the verbal record; but, viewing the events in sequence and allowing for the time that must have elapsed between some of them, the whole period of recent history could have taken place in 200 years.

The period before 'recent history' is preserved in snatches of legend. These purport to recount the origins of some facets of the present-day world: how human beings came to inhabit the valley, how certain useful plants came into being, and how some social institutions happened to form. The myths are generally recounted as stories, not as facts, by these pragmatic people; and few, if any, would be prepared to swear that they are true. I suggest that they may be true in essence through expressing in symbols what must have actually occurred in earlier times. As archaeological and ethno-botanical findings gain in precision, we can hope to interpret more accurately the historical meaning of the origin myths.

Kumberag, near Kugmil (west of Minj), seems to have been the first settled habitat of a people who had formerly been semi-nomadic food-gatherers. Legend has it that the first man and woman 'came up out of the ground like bean-plants' at this site. I suggest that this is simply an elliptical way of saying that they were already accustomed to travelling about the area when they settled at Kumberag, as against any possibility that they might have migrated there at this time from some other part of the Highlands. The legend specified 'like bean-plants', which come up as recognizably beans; so the first Minj people were recognizably Minj people when they arrived at Kumberag. The people at Kumberag were joined by the male ancestor of the oldest phratry, an ignorant primitive who walked out of the bush where he had been foraging like a wild pig - that is, gathering and hunting. They taught him civilized speech, the art of house-building, and the other skills of settled social life before he went to another site and founded a strong clan with his wives and his sons. The image like a wild pig' is recurrent in Minj Yu (the Minj language). Men say they would like to act like wild pigs — brawling among themselves, and snatching women and food as they want them-but renounce this wish because of the demands 
of living together in groups. One clan has a legend that it is descended from a pig; this suggests that the myths of origin may not themselves be very old. All the myths of origin are consistent with, and some can be interpreted as contributing directly to, a view of the Minj people's early ancestors as foodgatherers and hunters.

These must have been the people who made and used the pestles and mortars. The early women probably carried these implements in the net bags of the kind that still dangle from their descendants' heads; these bags would seem to be more serviceable for carrying chattels on the march than for transporting loads of sweet potatoes from garden to residence. What the early Minj people ground in these mortars is not certain. From the possibilities Bulmer lists when considering (1964b) hunting and gathering in the Highlands generally, the oak-like Castanopsis nuts would seem the most likely. But I would posit that the early Minj people may have ground the tiny Nothofagus beechnuts. This would make sense of an otherwise incomprehensible reference modern Minj people make to a certain fungus (possibly a kind of Hydnum) as 'the Nothofagus of the ancestors', though they themselves have no explanation of the symbolism involved. Grinding the Nothofagus beechnuts would be inconvenient and time-consuming, and so might readily stimulate a change to a settled mode of life as soon as the early Minj people found that tending gardens of tubers would be more efficient than gathering nuts. The discovery of a suitable tuber and its potentialities under cultivation would then explain why the stone mortars were not judged to be useful enough to be retained till modern times. It is hard to imagine what tuber could have induced the Minj people to adopt a settled life before the introduction of the sweet potato. Yams and taro are present, but the Minj methods of cultivating the particular varieties available could not have supported a population of any size. A wild Pueraria is present, but I have noticed it growing only on sites where cultivation would have been inconvenient and there is no tradition that it was ever cultivated. The sweet potato alone is quick-growing enough and easy enough to grow to account for such a dramatic change, and until more definite evidence of a pre-sweet potato agriculture can be produced I am inclined to posit that the Minj people have not been practising agriculture longer than 300 years or so. The sharp distinction contemporary Minj people draw between living 'like wild pigs' and living 'together' in communities of scattered homesteads suggests that the change may have indeed been dramatic, even planned, rather than a long acquisition of increasingly settled habits, and that the change may even have been as recent as I am suggesting here. 
WIVES AND WANDERERS

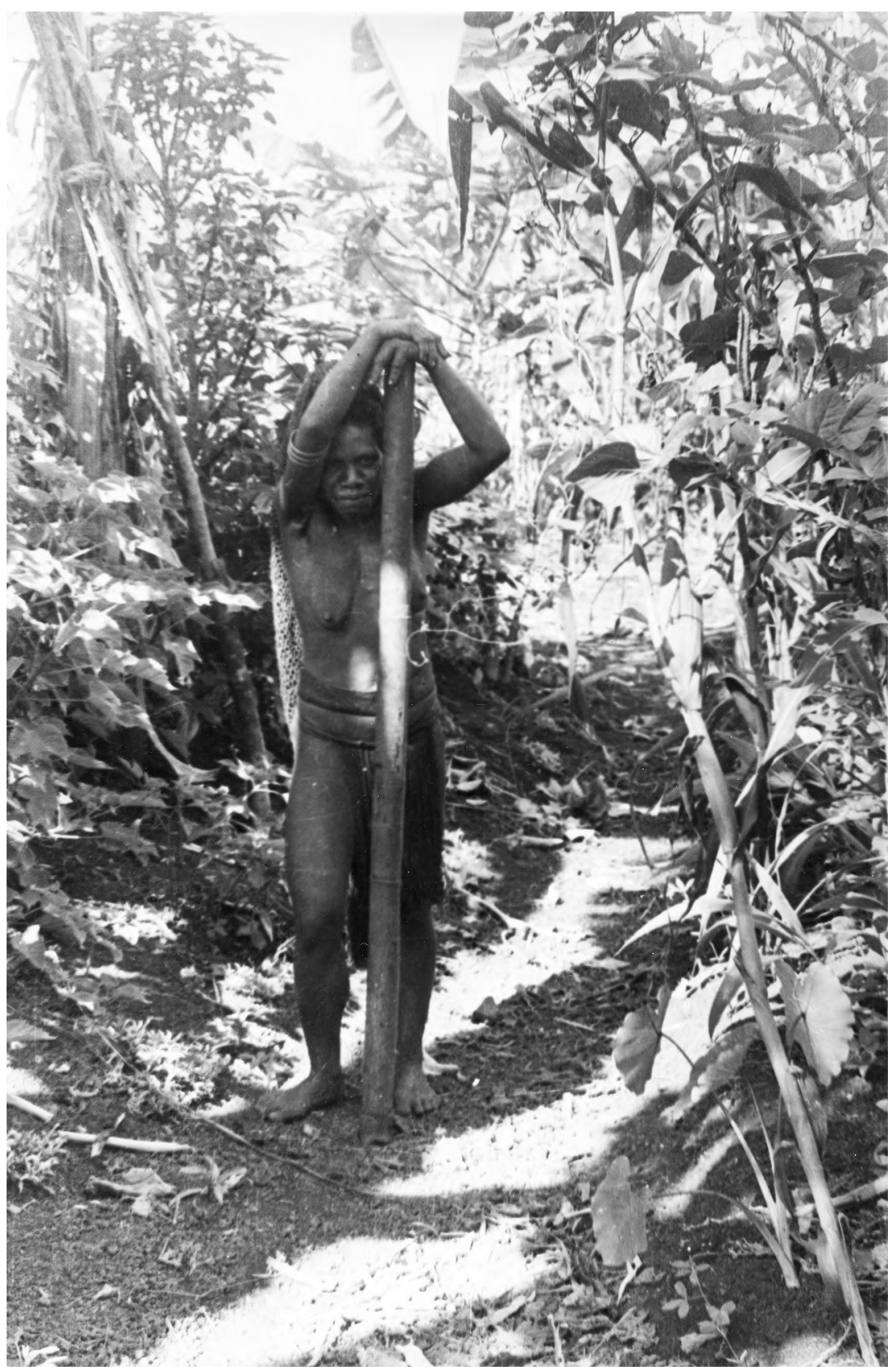

\section{Photograph 11: Woman in garden}

Source: Album 2 Reay 440/1194, Noel Butlin Archives 
It is possible that the change from a gathering economy to a settled agricultural one precipitated, accompanied, or even brought about a similarly dramatic change in the relation between the sexes. The prime motive for adopting a settled life would probably have been to facilitate the defence of expanding bands. The name for 'people in general' (Agamp), which includes the word for 'woman' but not that for 'man', ${ }^{3}$ expresses men's dependence on the opposite sex, ${ }^{4}$ but women must have been a distinct liability to their menfolk during skirmishes that took place wherever they happened to be during their wanderings. If my surmise that the stone mortars were used for grinding Nothofagus beechnuts is correct, the men could have used the imposition of this arduous and time-consuming task on the women as a means of 'getting back at' them for being necessary and burdensome to them. This would put men in two minds about the adoption of agriculture, for they might see it as a necessary step for their own protection from their enemies but an unfortunate opportunity for women to be emancipated from their drudgery.

Agriculture did not in fact emancipate the women from their drudgery, and the world of the Minj people was still a man's world when I was with them during 1953-55. The men haggled over the women, pigs, and material valuables that passed from clan to clan in a complex network of exchanges. The balance in these exchanges was important in the lives of the men; and women, pigs, and material valuables were male obsessions. The valuables they haggled over were the plumes and shell ornaments that formed their betrothal, marriage, and death payments and decorated their bodies when they were dancing.

'Women' they said contemptuously 'are nothing'. Females were simply the creatures who cared for a man's pigs and gardens, who bore and nourished a man's children and so contributed to the wealth and strength of his own and his forefathers' clan. They had no part to play in really important decisions - whether to go to war, whether to hold ceremonies, and whether to give a particular bride to this clan or to that.

3 See Editor's Introduction.

4 I suggest that when the male ancestor of Kuma phratry (standing for people who were still roving food-gatherers) had to learn 'civilized language' ( $Y u$ wi, true speech) at Kumberag after simply 'grunting like a pig', the change in his (their) language took the form of vocabulary expansion, formalization of verbal etiquette, and such matters which could have seemed crucial to the speakers but need not have involved radical structural alteration of the language. 
The Government had banned warfare. It had also banned personal violence. Formerly a man could drive an arrow into the thigh of his reluctant bride to ensure that she would not run away from him, but, although this practice still continued in side-valleys away from the Government Station, he would now be liable to go to jail if he were caught. The custom of the Minj people allowed a man to establish his right to a particular bride by giving her family (her parents, her brothers, and her father's clan brothers) a betrothal payment, regardless of her wishes. When he wanted to press his claim and take her to his home, he often had to take her by force. This, too, was against the white man's law.

One consequence of this curbing of violence was that the women of the Wahgi Valley were not so easily intimidated as they may have been before pacification. Still living in a man's world, they tended their pigs and gardens as before. But they rebelled openly against the arrangements the men made for them. Few girls suffered to be led unprotestingly to bridegrooms their families had chosen for them. Few women submitted without complaining when their husbands took new wives. I found the Minj people a quarrelsome lot who liked to settle their differences in public with florid verbosity, and the things they disputed about most were women and pigs.

Much of this book deals with women's protests, all true cases recorded as they happened during 1953-55, supplemented with further marriage disputes recorded in 1963-64 and with some information elicited retrospectively about the intervening period. I summarized the social institutions of the Minj people in my earlier book. Here, by presenting slices of Minj life, I want to show what kind of people the women of the Wahgi really are.

The men of Minj classified women in terms of two stereotypes of female behaviour-'wandering women' and 'good women'. Their opinion of women in general was so low that they thought that all would be 'wanderers' if they had a chance, but the behaviour of most women fell somewhere between the two extremes and much closer to that of the 'good women', the male ideal of what a woman ought to have been and rarely was, than to that of the 'wandering women', a label the men applied very readily to any who fluctuated from the ideal in any way. The idea of a 'wandering woman' embraces two Minj concepts- that of a woman who sought escape from the bonds of married life by running away to a clan that was a traditional enemy of her husband's, and that of 
a women who wandered perpetually from clan to clan and was unable to settle down to raise children and pigs in one place. I translate the two distinct vernacular concepts by a single term because the enemy's woman arriving in a clan's territory was treated as warriors might treat the spoils of war, even after formal warfare had ceased, and her having been the enemy's chattel justified the man treating her as if she had been unbroken to the ways of constancy and regular work. When it became clear that an occasional woman could not settle down, the men interpreted this as meaning that her insatiable lust had driven her to break the bonds they had woven for her and wander always in search of new sexual adventures. The men of Minj had a high regard for their social institutions but a low opinion of basic human nature. They admitted freely that they themselves would be 'like wild pigs'-greedy, selfish, and perpetually brawling - if they did not have their traditional rules of living to guide them. They averred that women, in the absence of social restraint, would have been irresponsible, lazy, and, above all, sexually insatiable. On this theory, which the men held, a 'wandering woman' was a woman who was not constrained by the ordinary demands of social living to curb her inner nature. When a women showed any signs of becoming a 'wandering woman' (and the men were quick to read such signs), the stigma of this label made it hard for her to maintain ordinary social relationships: the other women despised her for refusing to conform with the pattern they themselves tried to follow, and the men treated her as a common prostitute who was unable to demand a fee. The image of the 'wandering woman' was a powerful deterrent to women who felt inclined to stray from their allotted path, but it was not a wholly effective deterrent. Many women set out to see how far they could go in trying to circumvent the plans the men had made for them without actually acquiring the dreaded reputation with the uncompromising label.

The contrast with Australian Aboriginal women, with whom I have also worked, is startling. Aboriginal women also lived in a male-dominated society, but they accepted and even welcomed male dominance because it suited them to do so. While the men were preoccupied with the esoterica of initiation and ceremonial life-affairs of little consequence in the eyes of the women - the women themselves, freed from male surveillance, were able to enjoy the company of their peers and lead full and interesting lives of their own. Aboriginal sex life in the regions where I have worked seems to follow a clear pattern of dominance and submission between the respective sexes, with tenderness typically unrelated to sexual experience, and this 
pattern seems to have suited Aboriginal women well. The women of the Minj region, however, had not progressed beyond rebellion. They would have agreed with Radcliffe Brown's statement, which he made partly in jest, that marriage was fundamentally 'an act of hostility'. Their men had to achieve dominance, not simply take it for granted, in the sexual act, and the women themselves had to fight for the right to submit to them by putting up a losing struggle. ${ }^{5}$ An individual woman could come to a habit of submission after being married for some time, but relatively few seemed to do so. Although she herself was required to be faithful to the one man, her husband could avail himself of any opportunities the unmarried girls offered him and the favours of the adolescent girls brought him great prestige. A man who was successful in winning them was likely to neglect his wife, a woman who was his by definition and did not have to be sought to bring him prestige, and turn to her simply when he wanted to use her as a means of getting progeny. Often he neglected her long before she had an opportunity to demonstrate to him that she could be tamed into becoming a satisfactory sex partner for him.

Female anthropologists, because they have been Europeans dealing with native peoples subject to European domination, have often been able to penetrate the secrets of native men who have been used to hiding vast areas of ritual and other experience from their female associates. The work of Margaret Mead, Laura Bohannan, Kathleen Gough, and others shows this plainly. Male anthropologists, on the other hand, have been handicapped by a history of European men's sexual interest in native women; many have told me that they could not interview a native woman privately because the natives, including the woman herself, expected them to seduce her. But there have been many more male anthropologists than female anthropologists, and few male researchers have had wives who are anthropologists too. This means that anthropology has been too often a study by men of men, with a total neglect of the native women's viewpoint and an unconscious acceptance by male anthropologists of an outlook that subsumes male dominance in fields where it is not particularly natural or appropriate.

There is probably a good deal of truth in the popular assumption that the suppression of women in countries where their general status is low has come about through ignorance and ill will on the part of men.

5 See Appendix A. 
In the predominantly male culture of Minj, the suppression of women was crucial for the existence of the major institutions. Here was a society that depended upon the unreasonable quelling of female aspirations for its very continuance. Outside interference with one important element in the suppression of women-the breaking in of wild young fillies at adolescent marriage- has brought the Minj people to a cultural crisis at least comparable to the one they may have experienced when they gave up roving in the bush and settled down to tend their gardens.

Unmarried girls had an easy life in the early 1950s, for they had no pigs to tend and no pressing obligation to help their mothers in the gardens. Their 'work' was to attend certain ceremonies, held at night, which provided occasions for men and girls of intermarrying clans to meet. I have referred to these as 'courting ceremonies' because they introduced a youth to the field of girls from which his marriage partners would come, but they had little to do with individual courtship. The girls would gather in the house of a clansman whose wife belonged to the same clan as the visiting men. The visitors sat in a circle with their backs to the central fire, and the young hostesses formed an outer circle facing them. The men began a nasal singing while they and the girls swayed their bodies. The songs were simple, with a meaningless refrain after each line. They sang of birds and flowers, trees and rivers of different places and the girls who lived there. A favourite form of the song named another clan and proclaimed, 'Their girls have pretty noses, but the girls of this place also know how to turn their heads'. 'Turning their heads' was the main action of the courting ceremony. Both men and girls turned their heads from side to side as their bodies wove about. The faces of the men were intent and those of the girls dreamy as they moved in time to the hypnotic rhythm of the songs (see Photograph 5). A girl's face would come closer to that of one of the men beside her, and she would press her nose to his. They continued to turn their heads, ${ }^{6}$ using their joined noses as a pivot and pressing their cheeks together several times. Then the girl would draw away from the man, continuing to weave her body from side to side. She could repeat the action of rubbing noses and pressing cheeks with the same partner or with the man on the other side; she could continue to sway provocatively towards each in turn without coming into

6 This practice, common in many parts of the Central Highlands, is referred to as tanim het in Tok Pisin. 
contact with either; or she could rest awhile and quietly smoke a cigar. After a time, the men would change places and resume the actions with different partners.

When a man had built a new 'women's house' to accommodate the pigs in the care of a particular wife, young girls were again in demand for a house-opening ceremony. The girls of the wife's clan were invited to take over the house for an evening before she moved her pigs into it. Youths of the host clan cluttered the living room, with some forced to stand outside the door, while the girls sat in the individual pig stalls. A master of ceremonies called the names of particular men the girls had whispered to him and these men walked proudly into the section of the house where the girls waited. Much merriment resulted from the men's blundering efforts to find the right pig-stalls in the dark. Every man whose name had been called had been summoned by a particular girl to "carry leg' with her. This practice is described in Chapter 2.

After evenings of the first kind, the visiting men had to sleep in the house where the ceremony had taken place and sleeping arrangements ensured that no serious impropriety could take place after the fire was out and people were asleep. After evenings of both kinds, the visitors had to invite their hosts to a return ceremony held in their own clan territory. All friendly, intermarrying clans held such ceremonies. A man could not ask a girl to press her nose to his and show that she had chosen him as a partner. Nor could he ask her to have his name called to join her in the pig-stall of the new house. One who was never chosen simply gave up attending courting ceremonies of both kinds. One who was often chosen gained much prestige on account of his popularity with girls. Married men were not debarred from attending, and many did so, but these were always men who were confident that the girls would invite them to participate fully in the evening's entertainment.

There was no limit to the number of wives a man might have if he could afford the marriage payments for them. There were few polygynists at a particular time, but nearly every man would have been one if all the

7 Tok Pisin karim lek. Mihalic (Mihalic, F. 1971. The Jacaranda Dictionary and Grammar of Melanesian Pidgin. Milton, Qld: The Jacaranda Press, p. 107) defines the practice as a Middle Wahgi courtship practice where a girl sits on a boy's lap or alongside a boy, with both her legs across one of his thighs. Both parties rub noses for hours. 
wives he had ever had had stayed with him. A married man might have affairs with young girls who went to courting ceremonies, but a married woman's interest in other men counted as adultery.

The women did not accept this situation with docility. They preferred their husbands to be monogamous, and tried to drive away any extra wives who came. The wife of a man who went to a courting ceremony sometimes derided him, jeering that he thought he was still a good-looking youth. A woman finding her husband with a girl might attack him angrily.

Women were plainly jealous of their husbands' right to be as promiscuous as they themselves had been before marriage- not necessarily because they had insatiable sexual appetites but because they resented being treated as possessions or chattels of the men when this constituted a reversal of their positions of apparent power over the other sex during adolescence. Driving away co-wives as a man acquired them enabled a woman to keep her husband to herself; she could not effectively prevent him from obeying any invitations he might receive from girls to associate with them casually, but so long as no question arose of his marrying one of them she could demonstrate that she had some kind of power over him: in a sense, she could see him as a permanent possession of her own, much as the casual lovers of her adolescence had been temporary possessions she could discard at will. Women were jealous, too, of the particular co-wives who came to share their husbands, though such jealousy was only apparent towards co-wives from other clans than their own. Part of the trauma of marriage was the removal of the girl from her clan brothers and age-mates and her enforced residence in a community of strangers. She was able to help her clan brothers after marriage by encouraging her husband to make gifts to them and by nagging him to fulfil his material obligations towards them promptly; but once he gained a new wife from some other clan his obligations towards his affines were divided and the first wife's efforts on behalf of her brothers and her clan had to compete with the identical efforts of another woman representing different interests.

Once a woman married, she was no longer eligible to attend courting ceremonies. The ceremony of marriage itself was usually delayed until the woman was resigned to the loss of her single status; often, indeed, until she was clearly going to bear her husband's child. Marriages contracted during a clan's Pig Ceremonial, however, tended to be celebrated quickly because of the contribution the ceremony made to the general display of wealth at that time. At this ceremony, whenever it happened to be performed, 
the woman's brothers had to hand her over formally to her husband's group and receive the marriage payment in exchange. They would have already visited the husband and inspected the payment, haggling over individual items and discussing which had to be 'backed' by a return gift of equivalent goods.

The day before the 'marriage' ceremony, the bride's brothers killed a pig and cooked it to exchange for the pork the husband's group would bring. That night the girl's mother held a separate ceremony to cleanse and warm the skin of the bride. She built a great fire inside her house and drew a curtain of dried leaves across the doorway to trap the heat. The women of the subclan sat around the fire, singing songs similar to those of the courting ceremonies. The bride knelt before the fire and roasted herself until the sweat poured from her skin. Her skin had to be 'hot' to prepare her for marriage. (Ideally the same ceremony had been held before the bridegroom had taken her to his home, but girls could rarely be persuaded to participate willingly. Consequently some mothers alleged that their daughters' recalcitrance at the beginning of marriage was only to be expected when their skins were not 'hot' enough.) The women wiped the girl's skin with soft leaves, for the heat of the fire had to cleanse her skin and prepare her to be decorated the next day. The singing would continue far in to the night. This ceremony was primarily the business of women, but men and boys could be present to help them with the singing. It was a good opportunity for people not given to bathing to cleanse themselves as well as the bride.

The next day, the people of the bride's subclan gathered in the cooking grove to decorate her. Her mother took a gourd of pigs' grease from the house and rubbed it on the girl's skin to make her shine. Fluffy new bunches of cords, gifts from the wives of her father's clansmen, were brought and fastened over her old garments. The crescent-shaped goldlip pearlshell she wore at her throat was taken away to be polished by one of these women with leaves dipped in water, and then it was fastened around her throat again with several others. The women placed on her head an openwork skull cap, freshly netted, and in the spaces between the knots the men stuck feathers in the girl's springy black hair. They decorated her as for a big dance. She wore delicate earrings made of pieces of tree-kangaroo fur; a round white shell, looking like a slice of onion, hung from her nose; the glittering tail feather of an Enamel (King of Saxony) Bird of Paradise curved upward from each nostril (see Photograph 6). 
The bridegroom and his relatives arrived. One of the men carried the marriage payment, borne aloft on a bamboo banner fixed to a pole. Shell ornaments of various kinds covered both sides of the banner, and Bird of Paradise plumes waved in a row along the top and, in a large payment, around the edges. He planted the pole upright in the ground. The women of the party followed, laden with string bags full of pork, and great flaps of pork-fat were folded over their heads. They spread banana leaves on the ground and piled the pork on top of them.

The relatives of the bride brought her forward and an orator of her subclan made a speech. The men stood in two lines, and she had to pass between them (as along the aisle of a church) holding a hatchet, or sometimes a bush knife, upright in her hand. The pose with the raised hatchet was a ritual stance, and none of the Minj Agamp could explain it to me. The hatchet was to become the property of the bridegroom, but it seemed to me that the unconscious symbolism of the bride's pose had to do with her hostility towards the marriage and that she would have required little provocation to bring the hatchet down on her intended partner's head if he were standing nearby. In fact he remained in the background and had no particular role to play in the ceremony. One of the bride's male relatives took her free hand and gave it to a man of the bridegroom's group who was to have some measure of responsibility for her in her new community. The women who were married to the bridegroom's patrilateral ${ }^{8}$ relatives embraced her, uttering joyous cries of welcome and inviting her to be a 'sister' or 'daughter' to them.

Now it was time for both parties to exchange pork. The bride's brothers and subclan brothers held slabs of fat while she and the women already married into the bridegroom's group bit off tiny pieces. She herself did not eat the pork-fat but simply savoured the salty flavour and spat out the pieces, which children and other persons with no particular priorities in tasting pork on this occasion retrieved. The men of the bride-groom's group then held the flaps of pork-fat they themselves had contributed and let the bride's mother and other women of that group taste it. Then the men tasted it also. The formality over, the people of the two groups chattered happily together, often nibbling vegetable snacks they exchanged informally between them, until the bridegroom's relatives took the bride back to their home. The women of each group carried home the meat the other group had brought, to divide it later.

8 That is, the groom's relatives on his father's side. 
Marriage among the Minj Agamp was essentially a transaction between groups. One patriclan ${ }^{9}$ had given a bride to another patriclan for one of its members. The units that actually took part in the transaction were subclans, but they did this explicitly on behalf of their clans. The men intended her for a particular man of that clan, but the bridegroom had no part in the marriage ceremony. The bride's relatives handed her to another man, who was to watch her interests now that she was married. He would receive part of the first pig she reared for her husband. If she left to return to her parents and brothers, this man would bring her back. Later, if her husband's relatives ever accused her of illicit magical practices, this man would defend her.

The 'marriage' ceremony was repeated later when she had borne a child, for her husband was required to make a further payment to her clan for each child she bore, but by delaying the presentation of the initial marriage payment as long as possible an astute bridegroom could stave off the demands of predatory in-laws by complaining that he had just recently given them a substantial payment, and the relations between ostensibly friendly clans were complicated by lasting indebtedness. He was required to make yet another payment when she died and when a woman had outlived her husband their son owed this payment to his maternal uncles. A husband's clan had to pay more plumes and ornaments to her brothers when each of her children died. These payments went on beyond the lifetime of the individual parties to any marriage.

A man had a further motive in delaying the ceremony at which his marriage payment was handed to the bride's clansmen. Only when he knew that she was going to bear his child could he be certain that she would not leave him and go to another man. Men could and did use physical violence to intimidate their wives into staying with them in the old days, but this was increasingly hard to get away with in 1953-55. In a legend purporting to recount the origin of marriage, two women shot little arrows into a man's thigh to prevent him from leaving them. The bridegroom in the Minj area used to do this to a bride who tried to run away. If she persisted in her efforts to escape, he might drive a stake through her foot and tether her to his house. These cruelties had disappeared in 1953-55 excepting in the more remote places, but women's reluctance to enter the marriages arranged for them remained. They did not want to give up the freedom and status of their years of attending courting ceremonies, and they had no immediate interest in raising pigs and children.

9 A clan recruited through men, i.e. where a man's children belong to his clan, but his sisters to her husband's clan. 
At the time of my first arrival, three clans-Konumbuga, Kugika, and Tangilka-were preparing for the Pig Ceremonial. Traditionally a clan would hold this important festival at long intervals, ideally the time casuarina trees planted on the ceremonial grounds take to mature. Kugika clan had held its Pig Ceremonial fifteen years previously. Intervals between the festivals held by some of the other clans suggested that the accession of new wealth with the arrival of Europeans was shortening the interval a clan needed to build up its stock of pigs. The festival required many months of preparation, more months of dancing and display, and finally the climax came in a series of spectacular ceremonies and a mass slaughter of pigs. The central idea of the Pig Ceremonial was fertility-fertility in the clan's women, pigs, and gardens - and the consequent aggrandisement of the clan as an important, large, and wealthy group of patrilineally related males (see photographs 12,13,14 and 15 of ceremonies and festivals taken by Reay).

The Kugika men danced proudly on the ceremonial ground at Kondambi while their wives stood apart and watched the spectacle with wonder, admiration, and often obvious envy. The women themselves wore their drab working clothes - a bunch of greasy cords dangling from the waist at back and front. The splendid plumes and glittering shell ornaments were not for them, and they had no part in the men's dancing. Little girls and adolescents could deck themselves in plumes and shells and take part, but married women had to be content with watching.

Marriage was the dividing line between the good time and the hard time for women of the Minj Agamp. Beforehand, they selected their own partners at courting ceremonies and summoned men to be their companions in more intimate encounters. Afterwards, their life was dominated by the necessity of caring for gardens and pigs, of bearing and rearing children, of contributing to the wealth and strength of their husbands' clan. Everything suddenly became a chore. No bells rang at a Minj marriage service, but if they had done so they would have tolled for departed freedom and suppressed sexuality. Marriage was the time when a woman's own interests had to be suddenly subordinated to those of a man-of a man who was neither lover nor brother, neither a clansman with whom she had already learned to identify herself nor a tender companion whose interests could easily become her own. 


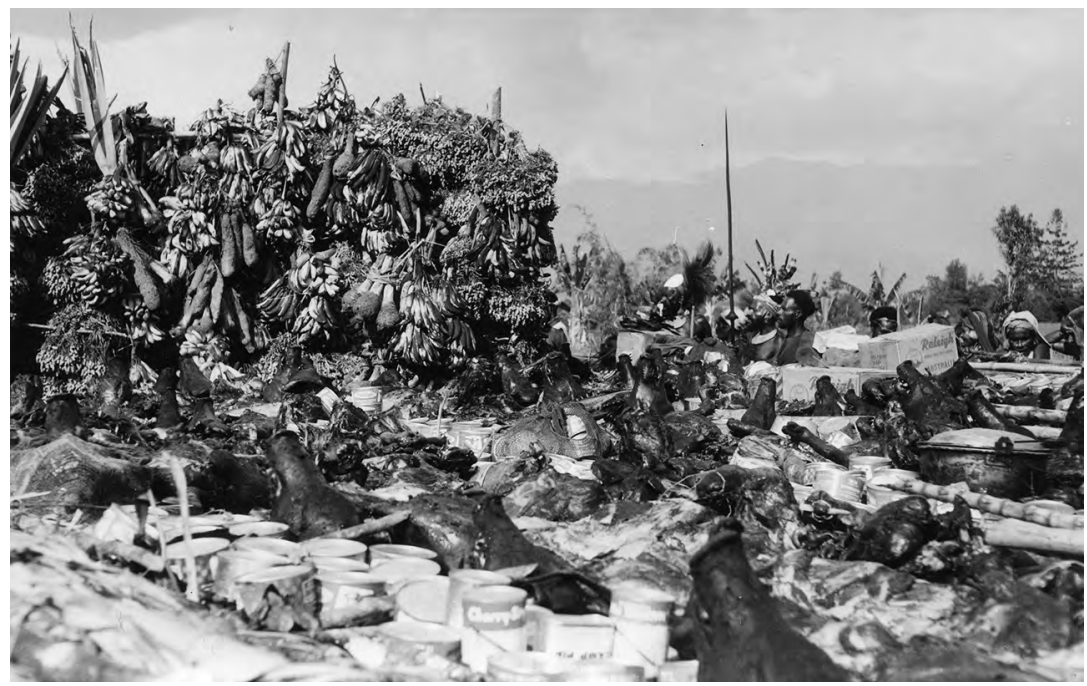

\section{Photograph 12: Pig feast}

Source: Album 6 Reay 440/1198, Noel Butlin Archives

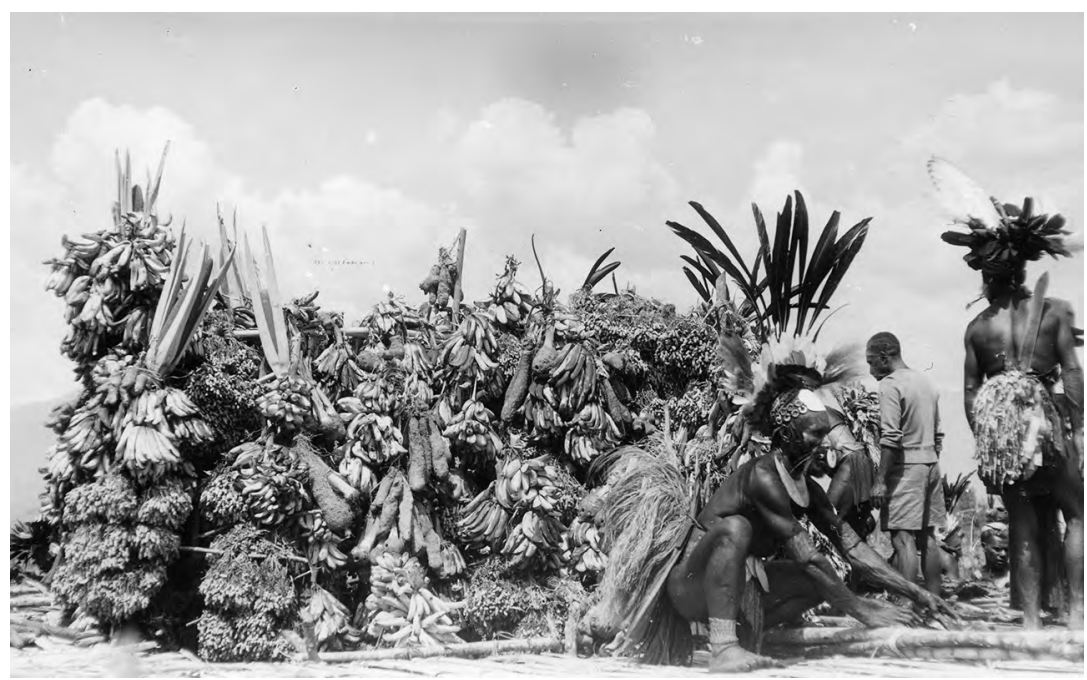

Photograph 13: Wubalt festival (harvest feast featuring pandanus nuts)

Source: Album 6 Reay 440/1198, Noel Butlin Archives 




Photograph 14: Feast with possible cult house

Source: Album 6 Reay 440/1198, Noel Butlin Archives

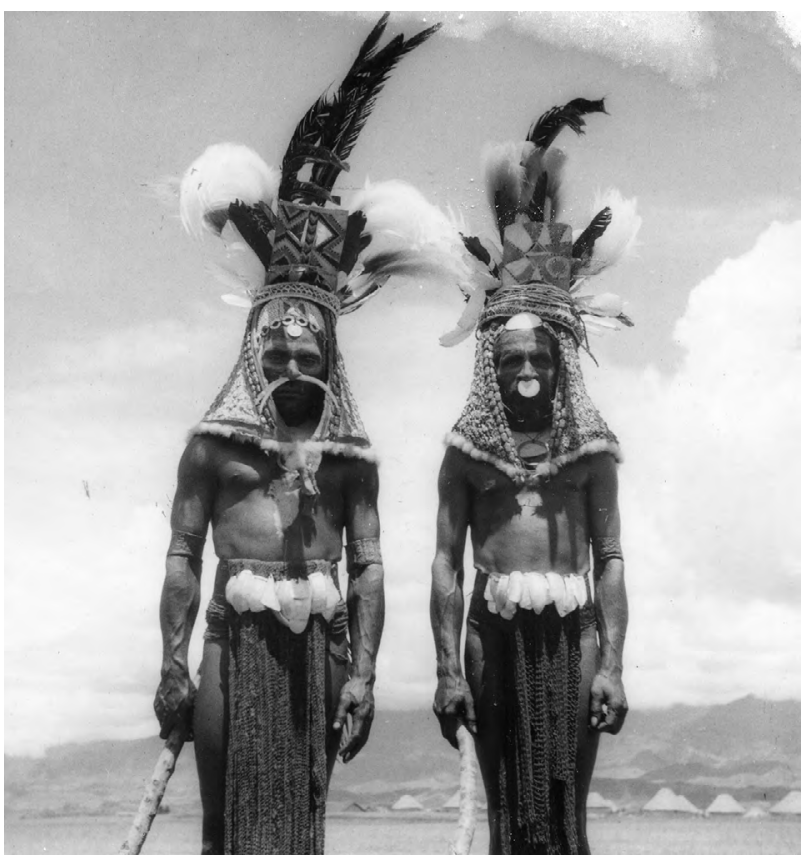

Photograph 15: Men wearing spirit boards

Source: Album 6 Reay 440/1198, Noel Butlin Archives 
This text is taken from Wives and Wanderers in a New Guinea Highlands Society: Women's lives in the Wahgi Valley, by Marie Olive Reay, published 2022 by ANU Press, The Australian National University,

Canberra, Australia.

doi.org/10.22459/WWNGHS.2022.01 